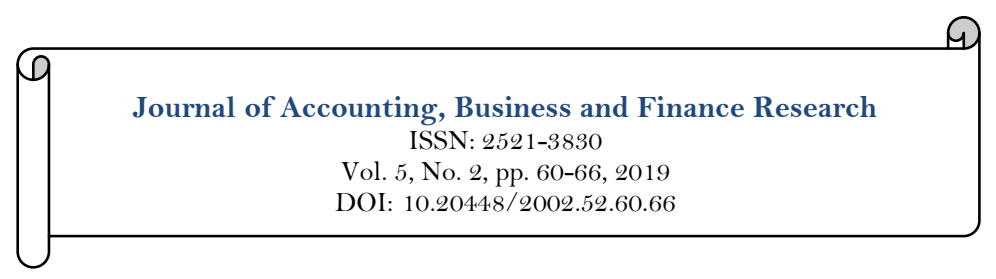

$\checkmark$ updates

\title{
Macroeconomic Determinants of Consumer Lending in Saudi Arabia
}

\author{
Saad M. Alnefaee \\ Department of Finance College of Administrative and Financial Sciences Saudi Electronic University, Kingdom of Saudi Arabia \\ Email:salnefaee@hotmail.com
}

\section{Abstract}

This paper empirically investigates the macroeconomic variables that influence consumer lending in Saudi Arabia using quarterly data for the period of 1996-2017. The Johansen and Juselius (1990) multivariate cointegration test were used to examine the impact of banks liquidity, interest rate, oil prices and GDP per capita on consumer lending. The test results indicate the existence of the long-term relationship and the empirical results show that consumer lending is positively influenced by a change in banks liquidity, growth in oil prices and GDP per capita. Contrary to expectation, the interest rate was positive and significant. The modified Granger causality test in Error Correction Model framework reports bidirectional causality from banks liquidity to consumer lending and vice versa, while unidirectional causality from GDP per capita and interest rate to consumer lending. The main finding of the paper is to encourage the monetary authority to allow for a gradual phase-out of restrictions on the number of personal loans as well as enhancing consumer protection mechanism to prohibit unfair contractual terms in the agreements.
Keywords:

Consumer lending

Ointegration

Oilprices

Granger causality

ECM

Banks liquidity

GDP per capita.

JEL Classification:

E. E5, E52.

Licensed:

This work is licensed under a

Creative Commons Attribution 4.0

License.

Publisher:

Scientific Publishing Institute

Funding: This study received no specific financial support.

Competing Interests: The author declares that there are no conflicts of interests regarding the publication of this paper.

\section{Introduction}

Consumer lending plays an important role in injecting liquidity in the economy and stimulates consumption and investment. Over the past several years substantial progress has been made to improve population access to the financial services. The introduction of financial sector reforms allowed for wider and more flexible forms of products, special attention was given to the introduction of Shariah-compliant products. The Saudi banks are enjoying a long history of liquidity surplus and low Nonperforming Loans (NPL). However, during the period of 2015-16 the country experienced economic shock caused by a sharp decline in oil prices that resulted in large government cuts in expenditure and payments to employees and suppliers. As a result, NPL increased slightly from 1.1 to 1.4 percent and corporate, household and government entity started withdrawing their deposits with banks to meet their needs (International Monetary Fund, 2017). Due to the pegged exchange rate regime, Saudi Arabian Monetary Authority (SAMA) introduced some macroprudential measures such as relaxing limits on loan to deposit ratio and transferring government funds and deposits to commercial banks to ease liquidity conditions. According to SAMA's classification, consumer loans consist of renovation and home improvement, vehicles and automobiles, credit cards, and others miscellaneous expenses such as education and marriage. Figure 1 illustrates the behavior of consumer loans from 1998 to 2017. Following the second Gulf war in 1993 the government financial institutions that considered the main source of free interest rate loans to citizens such as Real Estate Bank and Saudi Credit Bank have experienced a shortage in government funding. As a result demand for commercial lending by 
citizens started to increase rapidly to finance their personal expenses, where automobile financing reached 11 percent of total consumer loans for the period 1998-2005. Also, the introduction of Shariah compliance products has changed the consumers' attitude towards financing products offered by commercial banks. Consequently, demand kept rising at a steady rate until the year of the global financial crisis of 2007. To safeguard the banking system, SAMA tightened financial regulations such as restricting consumer loans where each monthly payment for the loan and credit card cannot go beyond 33 percent of the total salary of the borrower. Therefore, consumer loans declined despite the low interest rates. A few years later consumer loans rebounded sharply by 20 percent in 2011. This increase is associated with high oil revenue that increased deposit saving which resulted in banks liquidity surplus that enabled banks to offer more loans with low interest rates. The growth trend declined slightly in 2014 due to the sharp decline in oil prices that increased government budget deficit where banks shifted their lending priorities to the government.

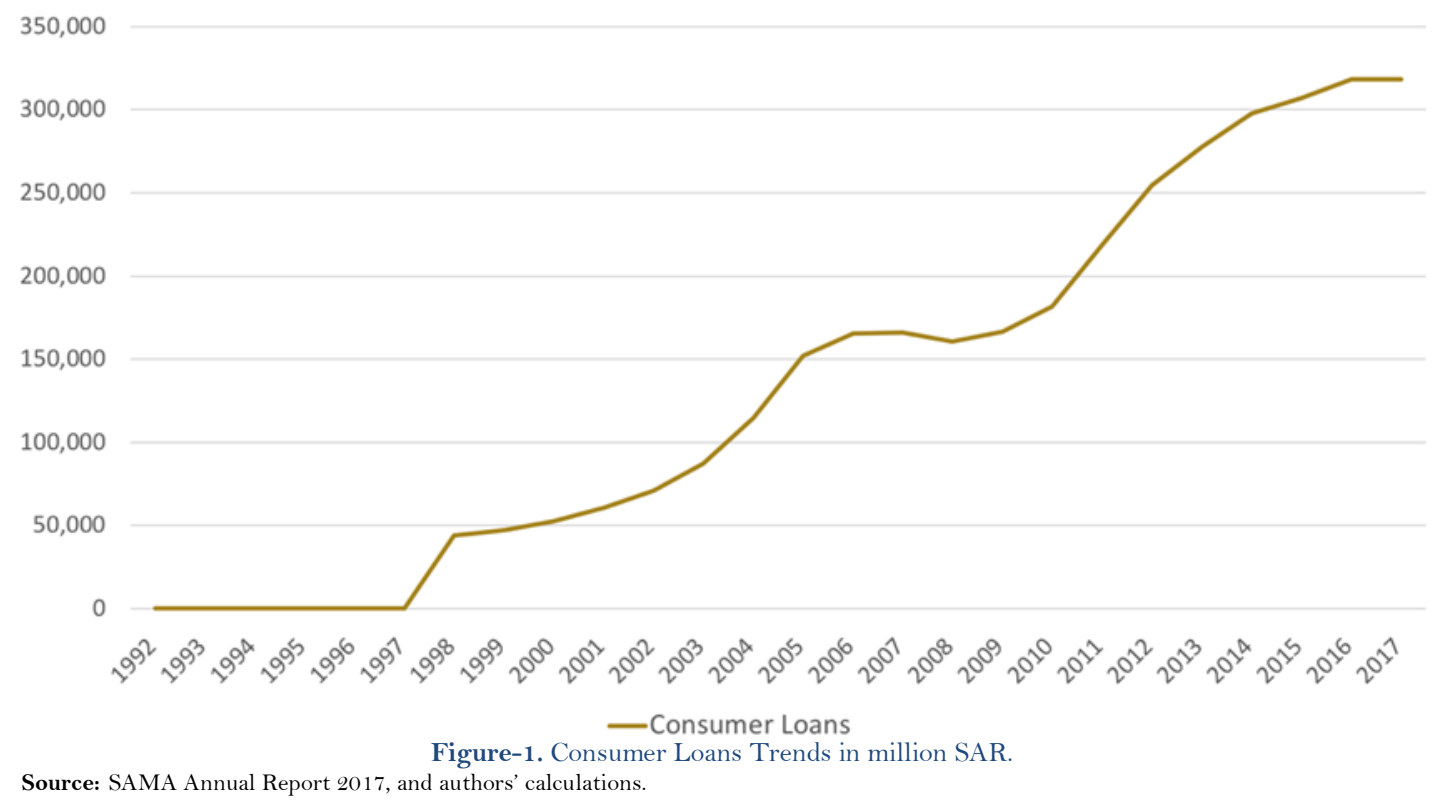

\section{Study Objectives}

Few studies have analyzed the factors influencing consumer lending behavior in Saudi Arabia. This paper is an attempt to contribute to the literature on consumer lending behavior in Saudi Arabia. Specifically, the paper objectives are (a) to examine the impact of growth in GDP per capita (wealth) on consumer lending (b) to explore the respond of consumer lending to changes in banks liquidity, oil prices and interest rate. In addition, the study will help policy makers to assess the impact of credit regulations on consumer lending.

\section{Literature Review}

Most of the current literature focused on general credit growth in developing and developed countries. The available literature considers consumers lending a function of supply-side factors such as banks liquidity and demand factor including income growth and interest rate.

Coletta, De Bonis, and Piermattei (2014) found that high per capita GDP is positively associated with household debt across 33 developing countries. Ahmed, Amanullah, and Hamid (2009) found that consumer loans in Pakistan were positively associated with banks liquidity, level of income and banking sector reforms. Ivanović (2016) studied determinants of consumer loans in Montenegro before the global financial crisis of 2007, the study concluded that GDP growth and banks liquidity have a major role in influencing consumer loans. Manole, Petrescu, and Vlada (2016) argued that the unemployment rate, consumer price index have influenced household loans in Romania. Yüksel, Zengin, and Kartal (2016) studied the impact of macroeconomic factors namely; interest rate and unemployment rate on consumer lending in Turkey. The authors found that interest rate has a positive effect, while unemployment rate exerts a negative impact on consumer lending. Stepanyan and Guo (2011) investigated the relationship between macroeconomic activities and consumer loans in Middle Eastern and North African countries using quarterly data. The study concluded that GDP growth has a positive effect on consumer lending.

In the context of Saudi Arabia, Abdul-Muhmin (2008) attributed the rise in household debt to the increasing banks' liquidity. Almutair (2015) argued that consumer lending is positively related to the stock market index. The recent study conducted by Miyajima (2017) examined macroeconomic variables influencing credit growth in Saudi Arabia. The study found that economic growth, oil prices and banks liquidity have a strong positive impact on lending. The interest rate was negative and insignificant. 


\section{The Model and Data}

Understanding the characteristics of the Saudi economy is important to set up a model that could explain the macroeconomic factors influencing consumers lending behavior. This study uses quarterly data for the period of 1996 -2017. We obtained data from various issues of the quarterly report of the Saudi Arabian Monetary Authority. Data on GDP per capita was obtained from the General Statistics Authority. Given the factors mentioned above, the consumer lending equation could be:

$$
\mathrm{CL}=f(\mathrm{LPC}+\mathrm{LR}+\mathrm{LB}+\text { oil }+\mathrm{Ut}) \text { with } \frac{\partial L c}{\partial L p c}>0, \frac{\partial L c}{\partial L B}>0, \frac{\partial L c}{\partial o i l}>0, \frac{\partial L c}{\partial L R}<0
$$

where

$\mathrm{LC}=$ Real consumers Loans

$\mathrm{LPC}=$ Real per capita GDP a proxy for domestic demand

$\mathrm{LB}=$ Real Banks Liquidity

Oil= Oil prices

$\mathrm{LR}=$ Real interest rate

$\mathrm{Ut}=$ The residual term

All variables are in $\log$ form,

\section{Methodology}

In many econometric time series data, simple trend models result in residuals that are serially correlated. To address this issue, the error correction model is used, where it uses current and past values of both independent and dependent variables to explain the current value of the dependent variable. Before employing (Johansen \& Juselius, 1990) technique to examine the existence of a long-run relationship between consumer lending and its determinants, Dickey-Fuller test is performed to check time series for stationarity.

\subsection{Cointegration and VECM Test}

Cointegration is a technique used to test whether or not there exists a long-run relationship between nonstationary economic variables. The Main idea behind cointegration is to show that variables are moving together toward a stable long-run equilibrium state. In the short-run, variable departs from each other as a result of disequilibrium. A simple error correction model can be represented as follows:

$$
\Delta \mathrm{Yt}=\theta_{\mathrm{O}}+\sum_{i=1}^{n} \alpha_{\mathrm{i}} \Delta \mathrm{Xt}-\mathrm{i}+\sum_{j=1}^{n} \beta_{\mathrm{j}} \Delta \mathrm{Y}_{\mathrm{t}-\mathrm{j}}+\rho_{1} \varepsilon_{\mathrm{t}-1}+\mu 1 \mathrm{t}
$$

Where $\varepsilon_{\mathrm{t}-1}$ represents an error-correction term lagged one period. It captures the speed of adjustment to the long-run equilibrium. However, before applying the Johansen and Juselius maximum likelihood estimation procedure technique, the degree of integration of each variable must be determined. The lag of each series is determined based on Schwarz Information Criterion (SC), Akaike information criterion (AIC), Hannan-Quinn Information (HQ) and LR test statistics.

\section{Results and Discussion}

\subsection{Test Results for Unit Roots}

According to the result in Table 1 the null hypothesis of unit root is rejected at both 1 and 5 percent levels. This suggests that each variable is non-stationary in the level and stationary in the first difference. No further tests are performed. We, therefore, maintain the null hypothesis that each variable is integrated of order one.

Table-1. Augmented Dickey-Fuller Tests, in Level and First Difference.

\begin{tabular}{c|c|c}
\hline Variables & ADF level & ADF: first difference \\
\hline LPC & $-1.53^{* *}$ & $6.83^{* *}$ \\
\hline LR & $-1.90^{*}$ & $-5.03^{* *}$ \\
\hline LB & $-1.32^{*}$ & $-5.99^{* *}$ \\
\hline OIL & $-1.64^{*}$ & $-6.70^{*}$ \\
\hline CL & $-1.65^{* *}$ & $-11.1^{* *}$ \\
\hline
\end{tabular}

- Rejection of the null hypothesis at ${ }^{*} 1$ percent level, ** 5 percent level.

\subsection{Cointegration Test Results}

The null hypothesis of no cointegration among variables (i.e., $r=0$ ) was rejected; the maximum eigenvalue test statistic exceeded the 95 percent critical values with the statistic when $r=1$ is less than the critical values. Thus, the results of the maximum eigenvalue test conclude that there is one cointegrating vector (CIV) while the trace test suggests five cointegrating equations. Following (Enders, 1995) and Maddala and Kim (1998) 
we prefer the maximum eigenvalue test result in determining the number of significant cointegrating vectors. Table 2 illustrates the tests results.

Table-2. Cointegration test results.

\begin{tabular}{|c|c|c|c|c|c|c|}
\hline $\begin{array}{c}\text { Null } \\
\text { Hypothesis }\end{array}$ & $\begin{array}{l}\text { Alternative } \\
\text { Hypothesis }\end{array}$ & $\begin{array}{c}\text { Max-Eigen } \\
\text { Statistic }\end{array}$ & $\begin{array}{c}0.05 \text { Critical } \\
\text { value }\end{array}$ & probability & $\begin{array}{c}\text { Trace } \\
\text { Statistics }\end{array}$ & probability \\
\hline$r=0$ & $r=1$ & 41.15 & 33.87 & 0.0057 & 105.6 & 0.000 \\
\hline $\mathrm{r}<=1$ & $r=2$ & 26.60 & 27.58 & 0.0670 & 64.5 & 0.0007 \\
\hline $\mathrm{r}<=2$ & $r=3$ & 17.01 & 21.13 & 0.1797 & 37.9 & 0.0046 \\
\hline $\mathrm{r}<=3$ & $r=4$ & 12.20 & 14.26 & 0.1042 & 21.1 & 0.0064 \\
\hline$r<=4$ & $\mathrm{r}=5$ & 8.92 & 3.84 & 0.0028 & 8.9 & 0.0028 \\
\hline
\end{tabular}

Table-3. Vector Error Correction Model estimates.

\begin{tabular}{|c|c|c|c|c|c|}
\hline \multicolumn{2}{|c|}{ Cointegrating Eq: } & \multicolumn{4}{|c|}{ CointEq 1} \\
\hline \multicolumn{2}{|c|}{$\operatorname{Ln}(\mathrm{CL}(-1))$} & \multicolumn{2}{|l|}{1.00} & & \\
\hline \multirow{2}{*}{\multicolumn{2}{|c|}{$\operatorname{Ln}(\mathrm{PC}(-1))$}} & \multicolumn{2}{|l|}{-0.62} & & \\
\hline & & \multicolumn{2}{|l|}{$[-0.93]$} & & \\
\hline \multirow{2}{*}{\multicolumn{2}{|c|}{$\operatorname{Ln}(\operatorname{Oil}(-1))$}} & \multirow{2}{*}{\multicolumn{2}{|c|}{-0.73}} & & \\
\hline & & & & & \\
\hline \multirow{2}{*}{\multicolumn{2}{|c|}{$\operatorname{Ln}(\mathrm{BL}(-1)$}} & \multicolumn{2}{|l|}{-0.44} & & \\
\hline & & {$[-3.8]$} & & & \\
\hline \multicolumn{2}{|l|}{$\operatorname{Ln}(\mathrm{R}(-1))$} & \multirow{2}{*}{\multicolumn{2}{|c|}{$\frac{-0.17}{[2.5]}$}} & & \\
\hline & & & & & \\
\hline \multicolumn{2}{|l|}{$\mathrm{C}$} & \multicolumn{2}{|l|}{0.76} & & \\
\hline Error correction & $\mathbf{D}(\mathbf{C L})$ & $\mathbf{D}(\mathbf{P C})$ & D(OIL) & $\mathrm{D}(\mathrm{BL})$ & $\mathbf{D}(\mathbf{R R})$ \\
\hline ECTt-1 & $-0.133^{*}$ & 0.03 & -0.01 & 0.01 & $0.72^{*}$ \\
\hline $\mathrm{D}(\mathrm{CL}(-1))$ & -0.11 & -0.01 & -0.84 & -2.55 & -0.720 \\
\hline $\mathrm{D}(\mathrm{CL}(-2))$ & $-0.41^{*}$ & -0.01 & 0.24 & 0.66 & 1.13 \\
\hline $\mathrm{D}(\mathrm{Oil}(-1))$ & -0.10 & -0.19 & -0.12 & 0.21 & 0.90 \\
\hline $\mathrm{D}(\mathrm{Oil}(-2))$ & -0.03 & -0.004 & 0.10 & -0.03 & 0.25 \\
\hline $\mathrm{D}(\mathrm{PC}(-1))$ & $0.14^{*}$ & -0.01 & 0.17 & 0.27 & 0.01 \\
\hline $\mathrm{D}(\mathrm{PC}(-2))$ & 0.05 & -0.03 & 0.10 & -0.03 & 0.25 \\
\hline $\mathrm{D}(\mathrm{R}(-1))$ & $0.10^{*}$ & -0.02 & 0.26 & -0.44 & $0.41^{*}$ \\
\hline $\mathrm{D}(\mathrm{R}(-2))$ & -0.03 & -0.07 & -0.003 & 0.09 & $-0.40^{*}$ \\
\hline Adj. R-squared & 0.50 & 0.045 & 0.075 & 0.128 & 0.660 \\
\hline F-statistics & 0.120 & 0.050 & 0.010 & 0.11 & 0.20 \\
\hline S.E. equation & 2.68 & 2.03 & 7.8 & 1.24 & 1.82 \\
\hline
\end{tabular}

Based on the empirical results above, the normalized conintegration equation for the factors influencing consumer loans in Saudi Arabia as follows:

$$
\begin{array}{ccccc}
\mathrm{CL}=0.76+0.44 \mathrm{BL}^{*}+0.73 \text { oil }^{*}+0.62 & \mathrm{PC}+0.17 \mathrm{R}^{*} \\
\text { t- stat } & 3.8 & 2.6 & 0.9 & 2.5
\end{array}
$$

\subsection{Long-Run Elasticity}

The normalized equation above indicates that variables are moving together toward a stable long-run equilibrium state. The economic interpretation of the long-run relationship among variables will be as follows:

1. Change in liquidity has a positive significant effect on consumer lending with a coefficient of 0.44 , this estimate means that a 1 percent increase in supply of banks liquidity on average increases demand consumer lending by 0.44 percent. In light of this result, one can say that liquidity surpluses encourage banks to offer a variety of lending products. This finding is consistent with Ahmed et al. (2009); Ivanović (2016); Stepanyan and Guo (2011) where they found a strong positive relationship between the rise in banks liquidity and increase in consumer loans.

2. Oil prices were found to be positive and significant indicating that an increase in oil prices by 1 percent on average increase the demand for consumer loans by 0.73 percent. This finding is consistent with reality, where Saudi Arabia is an oil-based economy, higher oil prices increase government revenues that could be translated into more government expenditure on consumption and investment as well as high savings that would be reflected in more supply of loanable funds. On the other hand, the lower oil price could force the government to approach commercial banks for lending that would crowds out consumer lending.

3. GDP per capita reflects the living standards and signals the economic conditions in the country. This variable result was positive but insignificant indicating that a one percent increase in GDP per capita 
leads to increases in consumer loans by 0.62 percent. This is consistent with Coletta et al. (2014), Miyajima (2017), Stepanyan and Guo (2011), Ming-Yen Teoh, Chong, and Mid Yong (2013). The insignificance of GDP per capita could be due to the monetary authority regulations that limit the monthly payment of personal loans to be 33 percent of borrower monthly salary.

4. Contrary to expectation, interest rate was positive and significant. A possible explanation is that Saudi Arabia has experienced low interest rates over the last twenty-five years. Another explanation for the significant effect is that government lending which is considered a better substitute for commercial lending has suffered a great funding reduction and, therefore, some borrowers have no option but to accept the ongoing interest rate to obtain adequate funds.

\subsection{Vector Error Correction Results}

The error correction term parameter or speed of adjustment ECT-1 (0.13) is negative and significant indicating that if the consumer lending level in last period was higher than what the long-run equilibrium relationship predicts by 1 percent, then there will be adjustment to reduce the consumer lending level by 0.13 percent in the current period to maintain the long-run equilibrium relationship. The short-run elasticity for banks liquidity is significant and smaller in magnitude than long-run. An interest rate is negative and significant with small coefficient compared to the long- run indicating that interest rate has a negative impact on consumer lending in the short-run. Both GDP per capita and oil prices were insignificant with smaller magnitude than the long run.

\subsection{Granger Causality in ECM Framework}

Following the work of Anwar, Davies, and Sampath (1996), Bengali, Khan, and Sadaqat (1999), Chuang (2000) and Narayan and Smyth (2004). The standard Granger causality test will be modified to incorporate the error-correction terms that are derived from the cointegration equation. The modified Granger causality test (causality in ECM form) consists of estimating the following:

$$
\begin{gathered}
\Delta \mathrm{Y}_{\mathrm{t}}=\theta_{0}+\sum_{i=1}^{p} \alpha_{\mathrm{i}} \Delta \mathrm{X}_{\mathrm{t}-\mathrm{i}}+\sum_{i=1}^{p} \beta_{\mathrm{i}} \Delta \mathrm{Y}_{\mathrm{t}-\mathrm{i}}+\rho_{1} \varepsilon_{\mathrm{t}-1}+\mu_{1 \mathrm{t}} \\
\Delta \mathrm{X}_{\mathrm{t}}=\theta_{1}+\sum_{i=1}^{p} \gamma_{\mathrm{i}} \Delta \mathrm{X}_{\mathrm{t}-\mathrm{i}}+\sum_{i=1}^{p} \lambda_{\mathrm{i}} \Delta \mathrm{Y}_{\mathrm{t}-\mathrm{i}}+\rho_{2} \varepsilon_{\mathrm{t}-1}+\mu_{2 \mathrm{t}}
\end{gathered}
$$

where $\varepsilon_{\mathrm{t}-1}$ represent error-correction term lagged one period.

Granger causality in the ECM form implies that there is two sources of causality for $\mathrm{Y}_{\mathrm{t}}$ and $\mathrm{X}_{\mathrm{t}}$ : lagged $\mathrm{Y}_{\mathrm{t}}$ and $\mathrm{X}_{\mathrm{t}}$; that is standard causality test, and $\varepsilon_{\mathrm{t}-1}$. The causality test in this form centers on the speed of the adjustment coefficients, which are $\rho$ 's. The inclusion of an error correction term that describes long-run causality gives an extra channel through which causality may be observed (Papapetrou, 2001). The inference of the causality in this procedure concerning causality between $\mathrm{X}_{\mathrm{t}}$ and $\mathrm{Y}_{\mathrm{t}}$ is based on the statistical significance of coefficients, $\rho_{1}, \rho_{2}, \alpha_{\mathrm{i}}$ and $\lambda_{\mathrm{i}}$. Accepting the null hypothesis of $\rho_{1}=0$ and, $\rho_{2}=0$ implies the absence of Granger causality. According to Anwar et al. (1996) applying Granger causality on Equations 3 and 4 requires three steps:

First, the following null hypotheses that $\rho_{1}=\rho_{2}=0$ and $\alpha_{i}=\lambda_{i}=0$ are tested. If we fail to reject the null hypothesis no further testing and no causality is detected. If the null hypothesis is rejected, causality is inferred; however, an assessment of whether the causality is related to short-run stationary variation or to the error-correction term, $\varepsilon_{\mathrm{t}-1}$ must be made.

The second step is to test the significance of $\alpha_{\mathrm{i}}$ and $\lambda_{\mathrm{i}}$, to check whether the source of causality is shortrun. The final step is the analysis of the direction of the $\rho$ 's to see if they infer a long-run equilibrium relationship. With this specification, change in $\mathrm{X}_{\mathrm{t}}$ or $\mathrm{Y}_{\mathrm{t}}$ can be attributed not only to the change in the rest of the explanatory variables in the equations, the standard causality inference, but also the long-run relationship among variables (Dakurah, Davies, \& Sampath, 2001). Toda and Phillips (1994) termed testing $\alpha_{\mathrm{i}}=\lambda_{\mathrm{i}}=0$ as short-run causality and testing the error correction term as long-run causality. A Wald Chi-square test was applied to test the joint significance of the sum of the lags of the explanatory variables, and the t-test is applied to the error correction terms. The non-significance of the error correction term refers to a long-run noncausality, and the absence of short-run causality is established from the non-significance of explanatory variables. Table 5 reports the results of the short-run causality in the ECM framework. The important factors causing a change in consumer lending are banks liquidity, interest rate and GDP per capita. Bidirectional causality from banks liquidity to consumer lending and vice versa, unidirectional long-run causality was found from oil prices interest rate and banks liquidity to consumer lending. This finding implies that change in interest rate and banks liquidity influence consumer lending in both short and long-run. 
Table-4. Long-run Causality for Consumer Lending

\begin{tabular}{c|c|c}
\hline Dependant variable & $\boldsymbol{\varepsilon}_{\mathrm{t}-1}$ & T-value \\
\hline LC & -.13 & 2.7 \\
\hline LB & .010 & 0.04 \\
\hline LPC & 0.03 & 0.21 \\
\hline LO & .060 & 0.36 \\
\hline LR & 0.72 & 1.6 \\
\hline
\end{tabular}

Source: Authors' estimates.

Table-5. Result of Short-run Granger Causality for Consumer Lending.

\begin{tabular}{l|c|c|c}
\hline Null Hypothesis & Chi-square & p-value & decision \\
\hline LB doesn't Granger Cause LC & 21.5 & .007 & Reject the null \\
LC doesn't Granger Cause LB & 15.81 & .01 & Reject the null \\
\hline LR doesn't Granger Cause LC & 11.23 & .05 & Reject the null \\
LC doesn't Granger Cause LCRD & 3.30 & .66 & Accept the null \\
\hline LO doesn't Granger Cause LC & 3.9 & .60 & Accept the null \\
LC doesn't Granger Cause LO & 4.01 & .55 & Accept the null \\
\hline LP doesn't Granger Cause LC & 14.1 & 0.01 & Reject the null \\
LC doesn't Granger Cause LP & 1.11 & .95 & Accept the null
\end{tabular}

Source: Authors' estimates.

\section{Conclusion and Recommendations}

Monetary Authorities have introduced many financial reforms to ease funding and increase the efficient allocation of financial resources. However, the share of consumer lending in the total commercial lending is less than 17 percent, which is low compared to the level in GCC countries such as Kuwait and the UAE.

The objective of this paper is to contribute to understanding the macroeconomic factors that influence consumer lending in Saudi Arabia for the period of 1996-2017. The cointegration technique and the VECM were employed to estimate the long and short-run relationship among variables. The main finding indicates that consumer lending is positively influenced by change in liquidity in the banking system. This finding suggests that the monetary authority, in this case, SAMA, through its regulatory power should allow the gradual phase-out of restrictions on the quantity of personal loans, because this quantity restriction may indirectly weaken the assets prices and the role of credit channel in the monetary policy. Moreover, the abundant liquidity in the banking system allows for greater scope for credit expansion that could improve household access to financial resources and increase the leverage of the monetary policy. Finally, the consumer protection mechanism is needed to help address consumer complaints and prohibit unfair contractual terms in consumer lending agreements.

\section{References}

Abdul-Muhmin, A. G. (2008). Consumer attitudes towards debt in an islamic country: Managing a conflict between religious tradition and modernity? International Journal of Consumer Studies, 32(3), 194-203.

Ahmed, A., Amanullah, A., \& Hamid, M. (2009). Consumer perception and attitude towards credit card usage: A study of Pakistani consumers. Journal of Comparative International Management, 12(1), 47-57.

Almutair, S. (2015). Dynamics of the relationship between bank loans and stock prices in Saudi Arabia. International Business Eं Economics Research Journal (IBER), 14(3), 439-452.

Anwar, M. S., Davies, S., \& Sampath, R. (1996). Causality between government expenditures and economic growth: an examination using cointegration techniques. Public Finance= Finances Publiques, 51(2), 166-184.

Bengali, K., Khan, A. H., \& Sadaqat, M. (1999). Money, income, prices, and causality: The Pakistani experience. The Journal of Developing Areas, 33(4), 503-514.

Chuang, Y. c. (2000). Human capital, exports, and economic growth: A causality analysis for Taiwan, 1952-1995. Review of International Economics, 8(4), $712-720$.

Coletta, M., De Bonis, R., \& Piermattei, S. (2014). The determinants of household debt: A cross-country analysis. SSRN Electronic Journal.

Dakurah, A. H., Davies, S. P., \& Sampath, R. K. (2001). Defense spending and economic growth in developing countries: A causality analysis. Journal of Policy Modeling, 23(6), 651-658.

Enders, W. (1995). Applied econometrics time series. New York: Wiley.

International Monetary Fund. (2017). Financial sector assessment program report. Washington D.C: International Monetary Fund.

Ivanović, M. (2016). Determinants of credit growth: The case of Montenegro. Journal of Central Banking Theory and Practice, 5(2), 101-118.

Johansen, S., \& Juselius, K. (1990). Maximum likelihood estimation and inference on cointegration-with applications to the demand for money. Oxford Bulletin of Economics and Statistics, 52(2), 169-2 10.

Maddala, G., \& Kim, I.-M. (1998). Unit roots cointegration and structural change UK: Cambridge University Press.

Manole, S., Petrescu, C., \& Vlada, R. (2016). Determinants of household loans. Theoretical and Applied Economics, 4(609), 89102 . 
Ming-Yen Teoh, W., Chong, S.-C., \& Mid Yong, S. (2013). Exploring the factors influencing credit card spending behavior among Malaysians. International Journal of Bank Marketing, 31(6), 481-500.

Miyajima, K. (2017). What influences bank lending in Saudi Arabia?: International Monetary Fund.

Narayan, P. K., \& Smyth, R. (2004). Temporal causality between human capital and real income in cointegrated VAR processes: Empirical evidence from China, 1960-1999. International Journal of Business and Economics, 3(1), 1-11.

Papapetrou, E. (2001). Bivariate and multivariate tests of the inflation-productivity Granger-temporal causal relationship: evidence from Greece. Journal of Economic Studies, 28(3), 213-226.

Stepanyan, V., \& Guo, K. (2011). Determinants of bank credit in emerging market economies (pp. 11-51): International Monetary Fund.

Toda, H. Y., \& Phillips, P. C. (1994). Vector autoregression and causality: A theoretical overview and simulation study. Econometric Reviews, 13(2), 259-285.

Yüksel, S., Zengin, S., \& Kartal, M. T. (2016). Identifying the macroeconomic factors influencing credit card usage in Turkey by using MARS method. China-USA Business Revierw, 15(12), 611-615. 